\title{
$\theta$
}

Journal of Business Management and Economic Research

2020, 4 (1) DOI: 10.29226/TR1001.2019.183

Journal Homepage: https://www.jobmer.org

\section{ORGANIZATIONAL STRUCTURE INFLUENCE ON CONSTRUCTION WASTE MANAGEMENT AMONG PENANG MALAYSIAN CONSTRUCTION INDUSTRY: AN APPROACH VIA PARTIAL LEAST SQUARE STRUCTURAL EQUATION MODELING}

\author{
A. Kanimoli ${ }^{1}$, A. Q. Adeleke* ${ }^{2}$, T. T. Taiwo ${ }^{3}$ \\ 1,2Faculty of Industrial Management, Universiti Malaysia Pahang, Lebuhraya Tun Razak, 26300, \\ Gambang, Pahang, Malaysia \\ ${ }^{3}$ School of Accounting and Finance, University of East London \\ *Corresponding author: adekunle@ump.edu.my
}

\begin{abstract}
The construction industry is one of the industries that contribute to the economies of Malaysia and to be considered as a significant element to the Malaysia economy. At the same time, when the number of construction projects increases, the number of waste generated by the construction projects also increases which has many negative impacts on the environment and public health as well. In order to reduce the number of waste generated by construction projects, the waste must be properly handled and there must be effective construction waste management practices in every construction industry. Besides, previous studies have stated that the number of construction waste regarding material waste, buildings waste and so on is increasing day by day. The number of waste is on the rise due to the absence of an effective organizational structure which is an important aspect of construction waste management. To address these issues above, this research paper aims to: 1) to investigate the relationship between formalization and construction waste management in Penang construction industries; and 2) to investigate the relationship between centralization and construction waste management in Penang construction industries. The data were collected from 89 respondents among Penang construction companies. In this research, the PLS-SEM technique was used to assess both the measurement and structural models. The result shows that there is a significant relationship between formalization and construction waste management among the construction companies operating in Penang. Centralized organizational structure and construction waste management was also found to be positively correlated in this study.
\end{abstract}

Keywords: Organizational Structure, Construction Waste Management, Formalization, Centralization. 


\section{Introduction}

According to Fredrickson, (1986), the framework for the facilitation of communications and efficient work process is the organizational structure of an organization and if there are poor organizational structure and lack of teamwork which lead to unequal distribution of tasks among departments and also directly affect the effective and efficient of construction waste management. Therefore, government policy plays a major role in executing the organizational structure for construction waste management and also the most important factor that influence effective and efficient construction waste management.

Nwufo, (2010) stated that waste management policy which is the enforcement of waste management laws in Nigeria facing g major problem. Based on the investigation, is revealed that waste management policy is not enforced and not really well understood by the employees. In turkey, wastes are generated because of some factors in the construction stage which include unused materials, incorrect materials, improper equipment and so on. Furthermore, in Hong Kong, various policies have been implemented in order to effectively manage the construction waste and Hong Kong also actively trying new construction waste management policies in line with the latest waste management ( $3 \mathrm{R}$ and polluter pays principles) philosophies (Adeleke et al., 2019; Taofeeq et al., 2019; Lu, et al., 2013).

According to Begum et al., (2007), construction waste generation in Malaysia has become one critical issue. This is a result of the rapid development of construction industries in Malaysia which leads to lots of construction waste been generated. Waste management system if not properly handled and managed will results in negative impacts on humans and the environment as well not only in Malaysia but also in any part of the world. The major issue that arises from the construction waste in Malaysia is illegal dumping of waste attitudes of contractors in the construction industry. In order to overcome these issues, Malaysia must start with the waste management hierarchy through specific construction waste regulations and also come out with some disposal strategies as well. One of the effective strategies in implementing effective and efficient construction waste management could be the organizational structure in Malaysia. The organizational structure will influence the effective construction waste management (Abulhakim \& Adeleke, 2019; Bamgbade et al., 2019).

In addition, if there is a high demand for construction projects in Malaysia, the amount of construction waste also will increase in Malaysia (Siti \& Noor, 2008). Based on a study reported by Rahmat and Ibrahim, (2007) $42 \%$ of $46 \%$ of illegal dumping of waste in Johor district is from construction waste. Moreover, according to Faridah et. al., (2004), more illegal dumpsite near along the road was discovered based on a study in Seberang Perai, Pulau Pinang. According to Jain, (2012), currently, in Asia, there are minimum construction waste management policies. So, there will be a need for national policies on 
waste management in order to overcome construction waste problems. Therefore, organizational structure plays a significant role in implementing effective construction waste management and further enhancing the sustainability of a company, particularly in the construction industry. Thus, every company must have its own organizational structure. So, having a proper organizational structure will allow a company to implement effective and efficient construction waste management (Taofeeq et al., 2019; Hassan \& Adeleke, 2019).

\section{Literature Review}

\subsection{Overview of the Malaysian Construction Industry}

One of the industries that engender wealth and the growth of the social and economies of the country is construction industries which are considered as the major stimulant to Malaysia economy. There were many types of industries in Malaysia that generates economic wealth towards the nation. However, construction industries contributing a significant effect on the economies of the country. In addition, there were also many Malaysian companies involved in construction sectors that provide economic strength that linked to the construction industry, construction projects provide jobs and also create the infrastructure crucial to keeping the nation moving forward. Nevertheless, the construction industry is one of the most challenge industries because it is risky and also one of the most booming industries in the whole world. Apart from that, according to the Department of Statistics, Malaysia (2019), the value of construction work done of RM36.5 billion in the fourth quarter of 2018 as recorded by Malaysian's construction sector.

Moreover, from the overall economic performance of Malaysia in 2018, 4.8\% contributed to the GDP by civil engineering and specialized construction industries. (Department of Statistics, Malaysia). According to Trading Economics, the global macro models and analytics expectations by the end last quarter of 2019, the Gross Domestic Product for construction in Malaysia estimated to be RM14727 million. In addition, the construction sector is one of the top 5 industry in Malaysia which has a direct contribution to the economic performance of Malaysia. In 2018, the construction sector was in fourth place which is $4.8 \%$ behind the services sector which contributed $54.8 \%$, the manufacturing sector which was $22.8 \%$ and the agriculture sector which was contributed $7.6 \%$ to the economic performances of Malaysia (Department of Statistics, Malaysia, 2019). Furthermore, the construction industry divided into two sectors which are non-residential (which including three sub-sectors which are heavy industrial, institutional and commercial engineering) and also residential sector. Therefore, each sector 
has its own merits with a varied and rewarding range of projects (Azman \& Adeleke, 2018; Bamgbade et al., 2019).

Basically, once the organizational goals were set, which is a way of maintaining the standards, rules, and procedures in guiding the employees in order to achieve the organization's goals is called formalization. (Auh and Menguc, 2007). Furthermore, in order to control the employees from carrying out different activities in the performance of routine work in the construction waste management, the formalization of the organization needs to be established in an organization (Adeleke et al., 2019; Taofeeq et al., 2019; Aiken and Hage, 1971). According to Amanda L. Webster, (2019), the formalized organizational structure concentrated on roles and positions instead of people in the positions. Amanda L. Webster also stated that formalization is a process which is by way of creating a formalized structure and includes the maintenance of the formal structure over time.

Centralized management is an approach by which a company makes the most important of its decisions at the top and focuses power at a single location or with an individual or small group of individuals. (Devra Gartenstein, 2019). Apart from that, a centralized organizational structure confines the managers in decision making and also the chief executive officers (CEO) or directors control the sole decision power in the construction waste management perspective. Thus, the centralized organizational structure gives authority to the managers and also the employees as well to make decisions and also performing their duties. (Hassan et al., 2019; Malik \& Adeleke, 2018; Katsikea, et al, 2011).

\subsection{Conceptual Framework}

This research is conducted using the specified model with clearly defined variables which are dependent and independent variables. Based on the conceptual framework, the independent variables are the formalized organizational structure and centralized organizational structure, and the dependent variable is the construction waste management (waste disposal). Thus, the framework shows the relationship between these variables. Therefore, the relationship between the formalized and centralized organizational structure is deeply related to the construction waste management among construction projects in the construction companies in Penang, Malaysia. 
$\underline{\text { Independent Variables }}$

Organizational Structure $\underline{\text { Dependent Variable }}$

Construction Waste Management

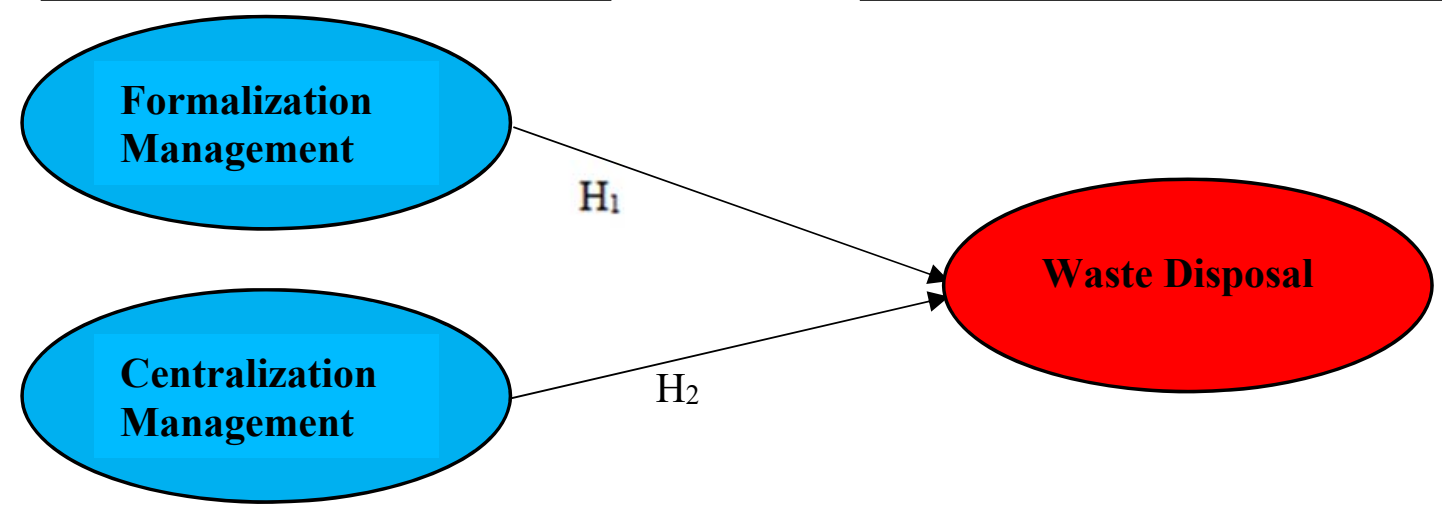

Figure 1: Conceptual Framework

\subsection{Relationship between Formalization and Construction Waste Management (Waste Disposal)}

In order to guide the employees in the organization, formalized organizational structure established as written description, rules and procedures. The effectiveness of construction waste management influenced by the different types of organizational structure. (Subani \& Adeleke, 2020; Subramaniam \& Nilakanta, 1996; Duncan, 1976). According to Black's Law Dictionary, 'the organization is hierarchical and bureaucratic' is known as a mechanistic organization which is characterized by highly centralized authority, formalized procedures and practices and also specialized functions which means the workers are working separately with their own assigned tasks.

According to Anderson, (2005), Pertusa Ortega, Zaragoza-Saez and Claver-Cortes, (2010), formal rules and standard policies and procedures control the decision making and working relationships in construction waste management organizations which are known as the formalization. In addition, the establishment of specific rules and procedures for the employees to get the job done based on the organization of construction waste management with a formal structure. (Bamgbade et al., 2019; Omer \& Adeleke, 2019; Katsikea et al, 2011). Therefore, it hypothesized thus:

Hypothesis 1: There is a significant relationship between formalization and construction waste management 


\subsection{Relationship between Centralization and Construction Waste Management (Waste Disposal)}

The centralization of sovereignty is established to be an essential problem to the effectiveness of an organization which is a centralized organizational structure. (Aiken \& Hage, 1971). This is because previous studies have stated that decentralized and informal organizational structures can help in achieving the effectiveness of construction waste management. Decision-making and the training concerning a functioning department in an organization are known as centralization. (Adeleke et al., 2018; Subramaniam \& Nilakanta, 1996). Moreover, according to Bedeian, (1986), the organizational efficiency in construction waste management will be an important subject in the study of organizations in order to determine the effectiveness of an organization.

The mechanistic structure in which the characteristics including centralization of authority, formalization of procedures and specialization of functions which directly improves the organizational efficiency in relation to the construction waste management. Most of the theorists hold to the point that centralization is and the extent to which decision-making for (financial, manpower, planning, and the organization's exceptional instances) is centralized at one point (Adeleke et al., 2016; Bamgbade et al., 2015; Taofeeq et al., 2020).

Hypothesis 2: There is a significant relationship between centralization and construction waste management

\section{Methodology}

The research design adopted by this study is a cross-sectional and quantitative approach which is one of the famous approaches used by social science researchers for their study. (Sekaran et al., 2001). Besides, the larger sample population is appropriate for quantitative methodology. (Adeleke et al., 2016; Kaya Yilmaz, 2013). By using a well-structured questionnaire to collect feedback from the respondent, the data was collected at single-point-in-time. (Sekaran and bougie, 2013). Therefore, the stratified random sampling technique was employed for sample selection for this study. This research was conducted among Seberang Perai, Penang construction companies and the total number of 89 samples was collected from the sample companies in Seberang Perai, Penang.

\subsection{Instrument Design}

The data collection technique used in this research is questionnaires to collect data from the respondent to get more information. Questionnaires are a convenient option to be considered when conducting a structured survey which including a combination of online surveys, email-based surveys, and self- 
administered survey are the types of surveys used for the data collection for this survey. (Adeleke et al., 2015; Nigel Mathers et al., 2006). SPSS was used for analysing the data for descriptive analysis of the respondent's demographic characteristics which includes position, company's year of existence, gender, company's prime location, company's ownership, work experience, number of full-time employees and company ownership. SmartPLS version 3.0 was also used to analyse the data for the relationship between the independent and dependent variables. Besides, a five-point Likert scale ranging from 1 (strongly disagree), 2 (disagree), 3 (neutral), 4 (agree) and 5 (strongly agree) was also used to measure items of the independent and dependent variable in order to get the feedback from the respondents. Items of the questionnaire were adopted from Kamaruddeen (2011) and were all the English language. But some improvement and modification were done on the items of the questionnaire to ensure the detailed information is provided. Then, all entire questionnaire was translated into Malay to make sure every respondent understands clearly about all items that stated in the questionnaire and the respondent can read and answer the questionnaire with clarity. All the variables in this research are multidimensional as presented in Table 1.

Table 1 Source of measurement

\begin{tabular}{lllll}
\hline S/N & Constructs & Dimension & Source & Remarks \\
\hline 1 & Organizational & Formalized and centralized & Yusuf Nasidi (2016) & Adapted \\
& structure & organizational structure & & \\
2 & Construction & Waste disposal & Mohammed Arif, Adapted & and \\
& waste & & Deepthi Bendi, and & \\
& management & & Tahsin Toma-Sabbagh, & \\
& & & $(2012)$ & \\
\hline
\end{tabular}

\section{Results}

\subsection{Data Collection and Sample}

100 sets questionnaires were distributed to the construction companies in Seberang Perai, Penang. However, 89 sets of questionnaires were returned after the distribution which represents $89.0 \%$ for the response rate which is acceptable in this research. Table 2 shows a summary of the demographic characteristics of respondents for this study (Bamgbade et al., 2015). 
Journal of Business Management and Economic Research (JOBMER), vol.4, issue.1, pp.56-73

Table 1. Summary of Demographic Scales of Respondents

\begin{tabular}{|c|c|c|c|}
\hline Type & Items & Frequency (N) & Percentage $(\%)$ \\
\hline \multirow{8}{*}{ Position } & Engineer & 29 & 32.6 \\
\hline & Project manager & 15 & 16.9 \\
\hline & Quantity surveyor & 9 & 10.1 \\
\hline & Contractors & 5 & 5.6 \\
\hline & Site clerk & 12 & 13.5 \\
\hline & Architect & 6 & 6.7 \\
\hline & Design team & 6 & 6.7 \\
\hline & Others & 7 & 7.9 \\
\hline \multirow{4}{*}{ Working experience } & 1-3 years & 49 & 55.1 \\
\hline & 4-6 years & 28 & 31.5 \\
\hline & 7-9 years & 10 & 11.2 \\
\hline & $>10$ years & 2 & 2.2 \\
\hline \multirow[t]{2}{*}{ Gender } & Male & 62 & 46.1 \\
\hline & Female & 56 & 53.9 \\
\hline \multirow{4}{*}{ Type of project } & Residential building & 38 & 42.7 \\
\hline & Commercial building & 22 & 24.7 \\
\hline & Educational building & 11 & 12.4 \\
\hline & Others & 18 & 20.2 \\
\hline \multirow[t]{3}{*}{ Company ownership } & Local & 73 & 82.0 \\
\hline & National & 13 & 14.6 \\
\hline & Others & 3 & 3.4 \\
\hline \multirow{4}{*}{$\begin{array}{l}\text { Company prime } \\
\text { location }\end{array}$} & Local market areas & 28 & 31.5 \\
\hline & Across Malaysia & 28 & 31.5 \\
\hline & Within a few states & 23 & 25.8 \\
\hline & International markets & 10 & 11.2 \\
\hline \multirow{4}{*}{ No. of employees } & $0-50$ & 17 & 19.1 \\
\hline & $50-100$ & 25 & 28.1 \\
\hline & $100-150$ & 29 & 32.6 \\
\hline & $>150$ & 18 & 20.2 \\
\hline \multirow{4}{*}{ Company existence } & $1-3$ years & 3 & 3.4 \\
\hline & 4-6 years & 37 & 41.6 \\
\hline & 7-9 years & 17 & 19.1 \\
\hline & $>10$ years & 32 & 36.0 \\
\hline
\end{tabular}




\subsection{Measurement Model}

Before examining the hypothesis, the measurement model and the outer model were tested through the partial least square structural equation modeling (PLS-SEM) technique. Figure 2 shows the model of this research with the structural dimensions below (Rahman \& Adeleke, 2018).

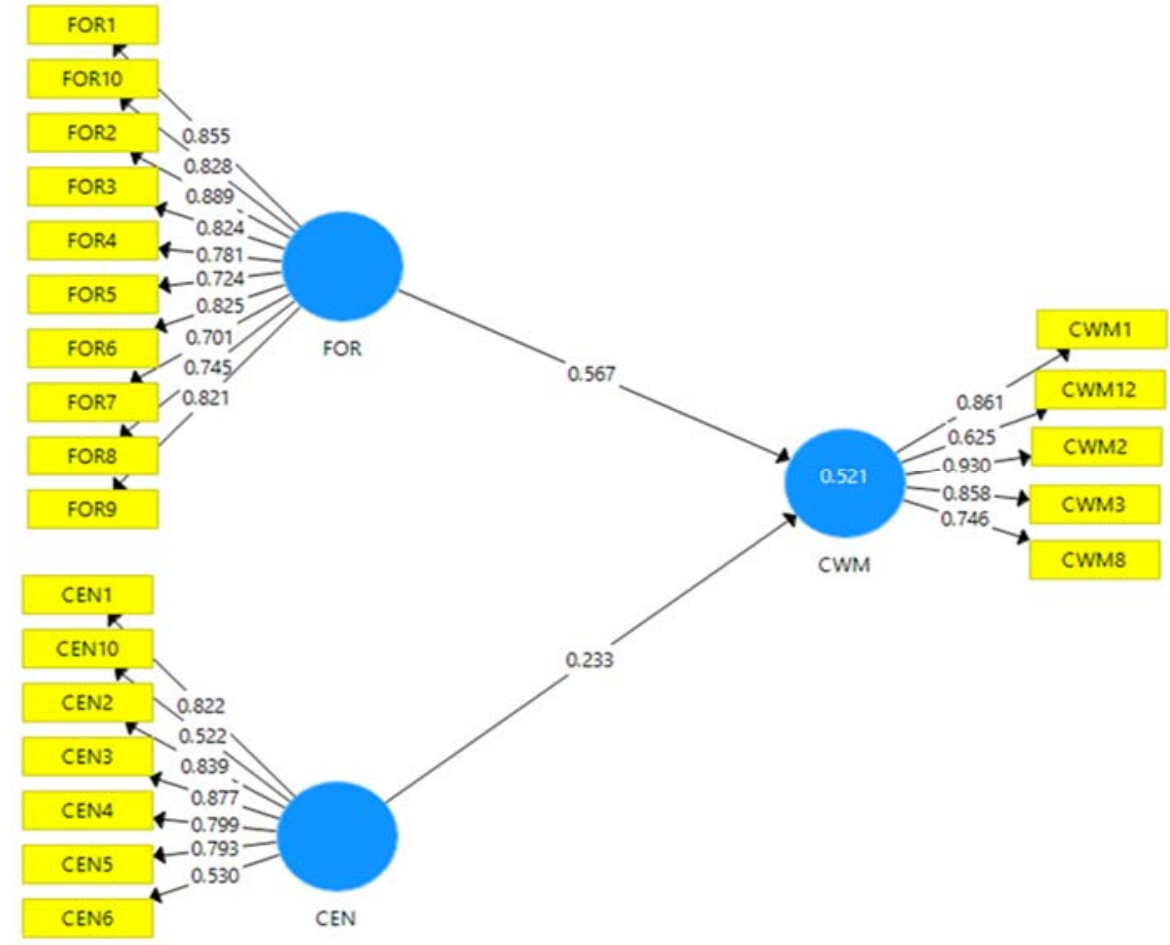

Figure 2: Measurement Model

Table 3 shows the content validity of the measurement used which can be explained in two manners. Firstly, there are high loading in the items on their respective constructs when related to other constructs. Secondly is the loading of the items were significantly loading on their respective constructs affirming the content validity of the measure used in this research (Adeleke et al., 2015; Chow and Chan, 2008). 
Table 3 Content validity

\begin{tabular}{llll}
\hline & CEN & CWM & FOR \\
\hline CEN1 & $\mathbf{0 . 8 2 2}$ & 0.429 & 0.434 \\
CEN10 & $\mathbf{0 . 5 2 2}$ & 0.277 & 0.172 \\
CEN2 & $\mathbf{0 . 8 3 9}$ & 0.359 & 0.417 \\
CEN3 & $\mathbf{0 . 8 7 7}$ & 0.369 & 0.365 \\
CEN4 & $\mathbf{0 . 7 9 9}$ & 0.396 & 0.434 \\
CEN5 & $\mathbf{0 . 7 9 3}$ & 0.596 & 0.603 \\
CEN6 & $\mathbf{0 . 5 3 0}$ & 0.299 & 0.297 \\
CWM1 & 0.495 & $\mathbf{0 . 8 6 1}$ & 0.577 \\
CWM12 & 0.435 & $\mathbf{0 . 6 2 5}$ & 0.364 \\
CWM2 & 0.480 & $\mathbf{0 . 9 3 0}$ & 0.627 \\
CWM3 & 0.460 & $\mathbf{0 . 8 5 8}$ & 0.683 \\
CWM8 & 0.341 & $\mathbf{0 . 7 4 6}$ & 0.513 \\
FOR1 & 0.419 & 0.611 & 0.855 \\
FOR10 & 0.518 & 0.601 & 0.828 \\
FOR2 & 0.499 & 0.61 & 0.889 \\
FOR3 & 0.466 & 0.497 & 0.824 \\
FOR4 & 0.388 & 0.445 & 0.781 \\
FOR5 & 0.275 & 0.447 & 0.724 \\
FOR6 & 0.324 & 0.581 & 0.825 \\
FOR7 & 0.536 & 0.712 & 0.701 \\
FOR8 & 0.427 & 0.431 & 0.745 \\
FOR9 & 0.483 & 0.488 & 0.821 \\
\hline
\end{tabular}

The convergent validity is considered to be the extent to which a group of variables converges to measure a specific concept. From that, the convergent validity is significant parts of validity to make sure the construct validity is related. So, to establish the convergent analysis, there are three criteria that were all measured at once, especially the factor loadings, composite reliability $(\mathrm{CR})$ and average variance extracted (AVE). Moreover, all items of loading were tested which is acceptable for all items. Then, its values must be more than 0.5 following the literature of the multivariate approach. Besides, the other criterion is the composite reliability (CR) to examine convergent validity (Sabodin \& Adeleke, 2018; Bamgbade et al., 2016). 
Table 4 Convergent validity

\begin{tabular}{|c|c|c|c|c|c|}
\hline $\begin{array}{l}\text { Construct } \\
\text { dimensions }\end{array}$ & Items & Loading & $\begin{array}{l}\text { Composite } \\
\text { Reliability }\end{array}$ & AVE & $\begin{array}{l}\text { Cronbach's } \\
\text { Alpha }\end{array}$ \\
\hline \multirow{8}{*}{ Centralization } & CEN1 & 0.822 & \multirow{8}{*}{0.899} & \multirow{8}{*}{0.567} & \multirow{8}{*}{0.866} \\
\hline & CEN10 & 0.522 & & & \\
\hline & CEN2 & 0.839 & & & \\
\hline & CEN3 & 0.877 & & & \\
\hline & CEN4 & 0.799 & & & \\
\hline & CEN5 & 0.793 & & & \\
\hline & CEN6 & 0.530 & & & \\
\hline & CWM1 & 0.861 & & & \\
\hline \multirow{4}{*}{$\begin{array}{l}\text { Construction } \\
\text { waste } \\
\text { management }\end{array}$} & Cwm12 & 0.625 & \multirow{4}{*}{0.904} & \multirow{4}{*}{0.658} & \multirow{3}{*}{0.866} \\
\hline & CWM2 & 0.930 & & & \\
\hline & CWM3 & 0.858 & & & \\
\hline & CWM8 & 0.746 & & & \multirow{11}{*}{0.938} \\
\hline \multirow{10}{*}{ Formalization } & FOR1 & 0.855 & \multirow{10}{*}{0.947} & \multirow{10}{*}{0.642} & \\
\hline & FOR10 & 0.828 & & & \\
\hline & FOR2 & 0.889 & & & \\
\hline & FOR3 & 0.824 & & & \\
\hline & FOR4 & 0.781 & & & \\
\hline & FOR5 & 0.724 & & & \\
\hline & FOR6 & 0.825 & & & \\
\hline & FOR7 & 0.701 & & & \\
\hline & FOR8 & 0.745 & & & \\
\hline & FOR9 & 0.821 & & & \\
\hline
\end{tabular}

To the construct validity of the outer model, the discriminant validity is essential. The discriminant validity is compulsory to be tested before the hypothesis is examined through path analysis. The measurement revealed that the degree to which items differ among constructs. Then, the discriminant validity shown that items used different constructs do not overlap. As illustrated in Table 5, the square root of AVE for all constructs was replaced at the diagonal elements of the correlation matrix. Therefore, the discriminant validity of the outer model for this study was confirmed where the diagonal elements in the table were higher than the other elements of the column and row where they are located. From the testing made above for the construct validity of the outer model, it is believed that the obtained results pertaining to the hypotheses testing should be highly reliable and valid (Ismayana \& Adeleke, 2020). 
Table 5. Discriminant validity

\begin{tabular}{llll}
\hline & CEN & CWM & FOR \\
\hline Centralization & 0.753 & & \\
Construction waste management & 0.545 & 0.811 & \\
Formalization & 0.550 & 0.695 & 0.801 \\
\hline
\end{tabular}

The hypothesized relationship is the next part that needed to be examined when the goodness of the outer model was confirmed. Using SmartPLS, the hypothesized model has been examined through the running of the PLS Algorithm. As illustrated in Figure 4.10, the path coefficients were generated. According to Table 6 below, the result shows the hypothesis testing. The result showed that formalized organizational structure (FOR) variable has a significant positive relationship on construction waste management $(\beta=0.567, t=6.248, p=0.000)$. Therefore, the $\mathrm{H}_{1}$ : the effect of formalized organizational structure on construction waste management was supported. Other hypothesis $\mathrm{H}_{2}$ (Centralized organizational structure) also have significant positive relationship on construction waste management $(\beta=0.233, t=2.222, p=0.013)$. So, both variables have a significant relationship on construction waste management among Penang Malaysian construction industries (Samsudin et al., 2020; Jamil \& Adeleke, 2018; Taofeeq et al., 2019).

Table 6. Hypothesis testing

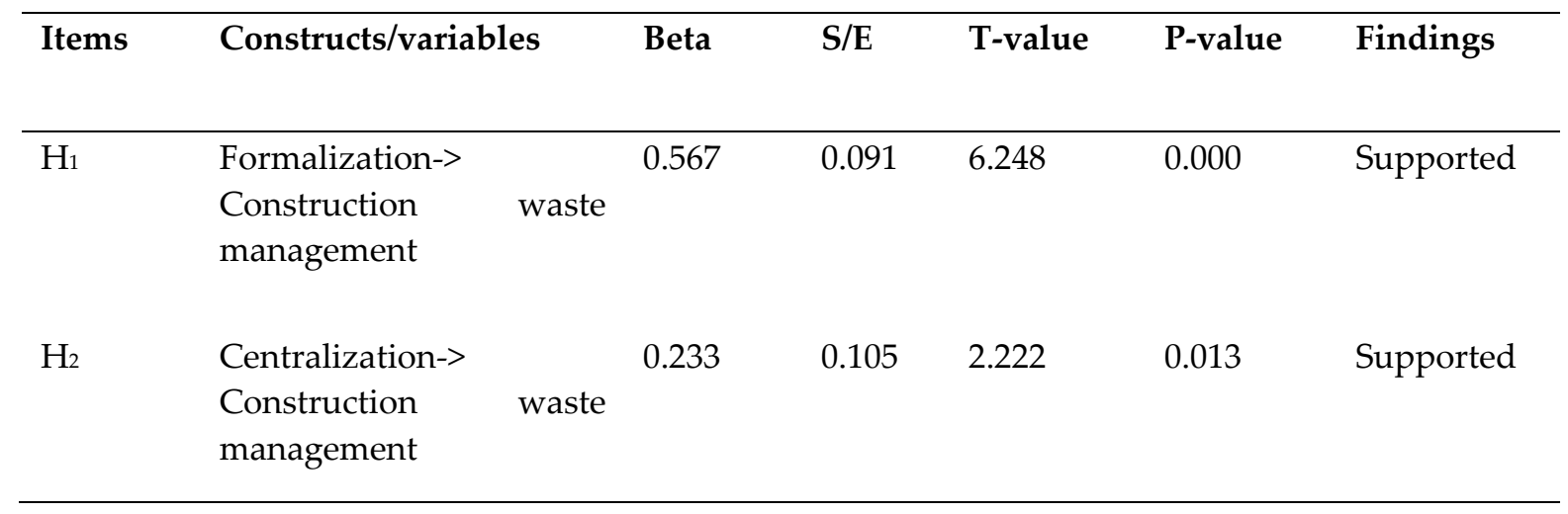

Cohen (1988) suggested that if the criteria of effect size is less than $0.02(0.02=$ small, $0.15=$ medium, $0.35=$ high). From Table 7, the effective size of formalization is large and centralization can be considered as small. The formula for calculating effect size is as shown below: 
Effect size $(\mathrm{f})=\mathrm{R}^{2}$ incl $-\mathrm{R}^{2}$ excl

$1-R^{2}$ incl

Table 7. Direct Effect IV-DV

\begin{tabular}{lllll}
\hline R-squared & Included & Excluded & f-squared & Effect size \\
\hline Formalization & 0.521 & 0.304 & 0.4530 & Large \\
Centralization & 0.521 & 0.486 & 0.0731 & Small \\
& & & & \\
\hline
\end{tabular}

\section{Conclusion and Implications}

This study focused on formalized and centralized organizational structure as an element of organizational structure on construction waste management in Penang Malaysian construction industries. Therefore, the future researcher can be explored to investigate a decentralized organizational structure or any other organizational structure elements on construction waste management and empirically validate the proposed model in this study.

Therefore, this study is important for the stakeholder whose work in construction industries especially the industries without effective construction waste management practices to improve the effective construction waste management and will also be of benefit to the academic world by contributing to the body of knowledge on construction waste management.

The contribution made by this research is both theoretical and practical where the addition of the existing literature about the formalization and construction waste management, centralization and construction waste is the theoretical contribution to this study. Besides, this study is one of the few studies that examine the effects of organizational structure on construction waste management Practically, this research can be of benefits to the employer such as managers, engineers, quantity surveyors and so on who are working on construction projects in the construction industries.

\section{Acknowledgment}

Authors of this study acknowledge the research funding from Universiti Malaysia Pahang managed by PNI, [Grant code: RDU190390]. 


\section{References}

Abulhakim, N., \& Adeleke, A. Q. (2019). The Factors Contributing to Accident Occurrence on Malaysia Building Projects through Partial Least Square Structural Equation Modeling. Social Science and Humanities Journal, 1096-1106.

Adeleke, A. Q. and Bahaudin, A. Y. and Kamaruddeen, A. M. and Bamgbaded, J. A. and M., Waris and Panda, Sitansu and Afolabi, Yakibi Ayodele (2019) An Empirical Analysis of Organizational External Factors on Construction Risk Management. International Journal of Supply Chain Management (IJSCM), 8 (1). pp. 932-940

Adeleke, A. Q., Bamgbade, J. A., Salimon, M. G., \& Lee, C. K. (2019). Project Management Performance and Its Influence on Malaysian Building Projects. KnE Social Sciences, 313-329.

Adeleke, A. Q., Windapo, A. O., Khan, M. W. A., Bamgbade, J. A., Salimon, M. G.,\& Nawanir, G. (2018). Validating the Influence of Effective Communication, Team Competency and Skills, Active Leadership on Construction Risk Management Practices of Nigerian Construction Companies. The Journal of Social Sciences Research, 460-465.

Adeleke, A. Q., Bahaudin, A. Y., \& Kamaruddeen, A. M. (2016, August). Rules and regulations as potential moderator on the relationship between organizational internal and external factors with effective construction risk management in Nigerian construction companies: a proposed framework. In AIP Conference Proceedings (Vol. 1761, No. 1, p. 020008). AIP Publishing.

Adeleke, A. Q., Nasidi, Y., \& Bamgbade, J. A. (2016). Assessing the Extent of Effective Construction Risk Management in Nigerian Construction Companies. Journal of Advanced Research in Business and Management Studies, 3(1), 1-10.

Adeleke$^{1}$, A. Q., Bahaudin, A. Y., \& Kamaruddeen, A. M. (2015). A Partial Least Square Structural Equation Modeling (PLS SEM) Preliminary Analysis on Organizational Internal and External Factors Influencing Effective Construction Risk Management among Nigerian Construction Industries. Rev. Téc. Ing. Univ. Zulia, 38(143), 143-55.

Adeleke, A., Bahaudin, A., \& Kamaruddeen, (2015) A Level of Risk Management Practice in Nigeria Construction Industry-From a Knowledge Based Approach. Journal of Management Marketing and Logistics, 2(1), 12-23.

Alvi, M. (2016). A manual for selecting sampling techniques in research.

Arif, M., Bendi, D., Toma-Sabbagh, T., \& Sutrisna, M. (2012). Construction waste management in India: an exploratory study. ConstructioInnovationon, 12(2), 133-155.

Arslan, H., Cosgun, N., \& Salgin, B. (2012). Construction and demolition waste management in Turkey. In Waste Management-An Integrated Vision: IntechOpen.

Azman, N. A. S. M., \& Adeleke, A. Q. (2018). Effect of Time Overruns on Apartment Building among Kuantan Malaysian Construction Industries. Journal of Advanced Research in Applied Sciences and Engineering Technology, 10 (1), 41-47.

Bamgbade, J. A., Salimon, M. G., Adeleke, A. Q., \& Nasidi, Y. (2019). Contractor's Technology Acceptance for Firm Sustainability Performance. KnE Social Sciences, 1084-1101.

Bamgbade, J. A., Nawi, M. N. M., Kamaruddeen, A. M., Adeleke, A. Q., \& Salimon, M. G. (2019). Building sustainability in the construction industry through firm capabilities, technology and business innovativeness: empirical evidence from Malaysia. International Journal of Construction Management, 1-16. 
Bamgbade, J. A., Kamaruddeen, A. M., Nawi, M. N. M., Adeleke, A. Q., Salimon, M. G., \& Ajibike, W. A. (2019). Analysis of some factors driving ecological sustainability in construction firms. Journal of cleaner production, 208, 1537-1545.

Bamgbade, J. A., Kamaruddeen, A. M., \& Nawi, M. N. M. (2016). Contractors' Environmental Sustainability: The Roles of Innovativeness and Market Orientation. Int. J Sup. Chain. Mgt Vol, 5(3), 185.

Bamgbade, j. A., Kamaruddeen, a. M., Nawi, m. N. M., \& aziz, z. (2015). Preliminary study on Antecedents of sustainable construction among contracting companies Operating in Malaysia. Jurnal Teknologi, 77(4).

Bamgbade, J. A., Kamaruddeen, A. M., \& Nawi, M. N. M. (2015). Innovativeness and Sustainability: Difference and Antecedent Relationship. Advances In Global Business Research Vol. 12, No. 1, ISSN: 1549-9332, 708.

Bedeian, A. G. (1986). Contemporary challenges in the study of organizations. Journal of Management, 12(2), 185-201.

Begum, R. A., Siwar, C., Pereira, J. J., \& Jaafar, A. H. (2007). Implementation of waste management anminimizationon in the construction industry of Malaysia. Resources, Conservation and Recycling, 51(1), 190-202.

Daft, R. L. (2015). Organization theory and design: Cengage learning. De Silva, N., \& Vithana, S. (2008). Use of PC elements for waste minimization in the Sri Lankan construction industry. Structural Survey, 26(3), 188-198.

Duncan, R. B. (1976). The ambidextrous organization: Designing dual structures for innovation. The management of organization, 1(1), 167-188.

Fauziah, S., Simon, C., \& Agamuthu, P. (2004). Municipal solid waste management in MalaysiaPossibility of improvement. Malaysian Journal of Science, 23(2), 61-70.

Fredrickson, J. W. (1986). The strategic decision process and organizational structure. Academy of management review, 11(2), 280-297.

Gayakwad, H. P., \& Sasane, N. B. (2000). Construction and demolition waste management in India. Development, 10, 12.

Gilpin, A. (1996). Dictionary of environment and sustainable development: John Wiley \& Sons Ltd.

Hair, J., Ringle, C., \& Sarstedt, M. (2011). PLS-SEM: Indeed a silver bullet. Journal of Marketing Theory and Practice. Journal of Marketing Theory and Practice, 19(2).

Hair Jr, J. F., Babin, B. J., \& Anderson, R. E. (2010). A GLOBAL P-ERSPECT-IVIE. Hassan, A. K., \& Adeleke, A. Q. (2019). The Effects of Project Triple Constraint on Malaysia Building Projects. Social Science and Humanities Journal, 1222-1238.

Hassan, A. K., Adeleke, A. Q., \& Hussain, S. (2019). Partial Least Square Structural Equation Modeling: An Approach to the Influence of Project Triple Constraint on Building Projects among Malaysian Construction Industries. Social Science and Humanities Journal, 1445-1464.

Ismayana, M. P., \& Adeleke, A. Q. (2020). The Influence of Organizational Culture on Construction Risk Management among Kuantan Malaysian Construction Industry: A Partial Least Square Structural Equation Modeling Approach. Social Science and Humanities Journal, 1693-1704.

Jain, M. (2012). Economic Aspects of Construction Waste Materials in terms of cost savings-A case of the Indian Construction Industry. International Journal of Scientific and Research Publications, 2(10), 1-7. 
Jaworski, B. J., \& Kohli, A. K. (1993). Market orientation: antecedents and consequences. Journal of Marketing, 57(3), 53-70.

Katsikea, E., Theodosiou, M., Perdikis, N., \& Kehagias, J. (2011). The effects of organizational structure and job characteristics on export sales managers' job satisfaction and organizational commitment. Journal of World Business, 46(2), 221-233.

Kulatunga, U., Amaratunga, D., Haigh, R., \& Rameezdeen, R. (2006). Attitudes and perceptions of construction workforce on construction waste in Sri Lanka. Management of Environmental.

Lu, W., \& Tam, V. W. (2013). Construction waste management policies and their effectiveness in Hong Kong: A longitudinal review. Renewable and sustainable energy reviews, 23, 214-223.

Malik, N. S. A., \& Adeleke, A. Q. (2018). The Effect of Organizational Culture on Material Risk among Malaysian Construction Industries. Journal of Advanced Research in Applied Sciences and Engineering Technology, 10 (1), 34-40.

Minks, W. (1994). The construction contractor's waste management plan: optimizing control and cost. Paper presented at the Proceedings of the 1st International Conference of CIB-TG16 Sustainable Construction, Tampa, FL, November.

Nagapan, S., Rahman, I. A., \& Asmi, A. (2012). Construction waste management: Malaysian perspective. Paper presented at the International Conference on Civil and Environmental Engineering Sustainability (IConCEES), Malaysia.

Narayana, T. (2009). Municipal solid waste management in India: From waste disposal to the recovery of resources? Waste Management, 29(3), 1163-1166.

N.D Jamil, A.Q. Adeleke (2018). The relationship between team competency and design risk management among construction industries in Kuantan. Journal of Advanced Research in Applied Sciences and Engineering Technology, 10 (1), 77-81.

Ng, L., Tan, L., \& Seow, T. (2017). Current practices of construction waste reduction through $3 R$ practice among contractors in Malaysia: Case study in Penang. Paper presented at the IOP Conference Series: Materials Science and Engineering.

Njoroge, B., Kimani, M., \& Ndunge, D. (2014). Review of municipal solid waste management: A case study of Nairobi, Kenya. International Journal of Engineering and Science, 4(2), 16-20.

Oluwaleye, M. (2012). Proposal for New Waste Management System in Nigeria. Seinäjoki University of Applied Sciences.

Omer, M. S., \& Adeleke, A. (2019). Systematic Critical Review of Risk Management in Malaysian Construction Companies. Journal of Humanities and Social Sciences Studies (JHSSS) Vol, 1.

Peng, C.-L., Scorpio, D. E., \& Kibert, C. J. (1997). Strategies for successful construction and demolition waste recycling operations. Construction Management \& Economics, 15(1), 49-58.

Pertusa-Ortega, E. M., Zaragoza-Sáez, P., \& Claver-Cortés, E. (2010). Can formalization, complexity, and centralization influence knowledge performance? Journal of Business Research, 63(3), 310-320.

Phrasisombath, K. (2009). Sample size and sampling methods. Faculty of Postgraduate. Pierce, J. L., \& Delbecq, A. L. (1977). Organization structure, individual attitudes, and innovation. Academy of management review, 2(1), 27-37.

Rahim, M., Kasim, N., Mohamed, I., Zainal, R., Sarpin, N., \& Saikah, M. (2017). Construction waste generation in Malaysia construction industry: illegal dumping activities. Paper presented at the IOP Conference Series: Materials Science and Engineering. 
Rajendran, P., \& Gomez, C. P. (2012). Implementing BIM for waste minimization in the construction industry: A literature review. Paper presented at the 2nd international conference on Management, Malaysia.

Rahman, N. F. A., \& Adeleke, A. Q. (2018). The Relationship between Effective Communication and Construction Risk Management among Kuantan Malaysian Construction Industries. Journal of Advanced Research in Applied Sciences and Engineering Technology, 10 (1), 18-24.

Reynaldo, J., \& Santos, A. (1999). Cronbach's alpha: A tool for assessing the reliability of scales. Journal of extension, 37(2), 1-4.

Saadi, N., \& Ismail, Z. (2015). Government Initiatives Pertaining to Construction Waste Minimization in Malaysia. International Journal of Energy and Environment, 9, 165-170.

Sabodin, N., \& Adeleke, A. Q. (2018). The Influence of Government Regulation on Waste Reduction Among Kuantan Malaysian Construction Industry. Journal of Advanced Research in Applied Sciences and Engineering Technology, 10 (1), 72-76.

Samsudin, N. S. A., Adeleke, A. Q., \& Ajibike, W. A. (2020). Effects of Contractors' Delay Factors on Building Project Performance Among Kuantan Malaysian Construction Industry. Social Science and Humanities Journal, 1705-1715.

Schultz, K. L., McClain, J. O., \& Thomas, L. J. (2003). Overcoming the dark side of worker flexibility. Journal of Operations Management, 21(1), 81-92.

Sekaran, U., \& Bougie, R. (2016). Research methods for business: skill-building approach: John Wiley \& Sons.

Subani, N. A., Adeleke, A. Q., \& Bamgbade, J. A. (2020). The Role of Organizational Culture on Sustainable Construction among Malacca Malaysian Construction Industry: A Partial Least Square Approach. Social Science and Humanities Journal, 1681-1692.

Subramanian, A., \& Nilakanta, S. (1996). Organizational innovativeness: exploring the relationship between organizational determinants of innovation, types of innovations, and measures of organizational performance. Omega, 24(6), 631-647.

Taofeeq, D. M., Adeleke, A. Q., \& Hassan, A. K. (2019). Factors Affecting Contractors risk attitude from Malaysia construction industry perspective. Social Science and Humanities Journal, 1281-1298.

Taofeeq, D. M., Adeleke, A. Q., \& Hassan, A. K. (2019). The Moderating Role of Government Policy on Contractors' Risk Attitudes in Malaysia Construction Companies. Social Science and Humanities Journal, 1261-1280.

Taofeeq, D. M., \& Adeleke, A. Q. (2019). Factor's Influencing Contractors Risk Attitude in the Malaysian Construction Industry. Journal of Construction Business and Management, 3(2), 59-67.

Taofeeq, D. M., Adeleke, A. Q., \& Lee, C. K. (2020). The synergy between human factors and risk attitudes of Malaysian contractors': Moderating effect of government policy. Safety science, 121, 331-347.

Taofeeq, D. M., Adeleke, A. Q., \& Lee, C. K. (2019). Individual factors influencing contractors' risk attitudes among Malaysian construction industries: the moderating role of government policy. International Journal of Construction Management, 1-20.

Thompson, V. A. (1965). Bureaucracy and innovation. Administrative science quarterly, 1-20.

Toledo, A. H., Flikkema, R., \& Toledo-Pereyra, L. H. (2011). Developing the research hypothesis. Journal of Investigative Surgery, 24(5), 191-194.

Wang, J.-Y., Kang, X.-P., \& Wing-Yan Tam, V. (2008). An investigation of construction wastes: an empirical study in Shenzhen. Journal of Engineering, Design, and Technology, 6(3), 227-236. 
Journal of Business Management and Economic Research (JOBMER), vol.4, issue.1, pp.56-73

Yuan, H. (2008). Construction and demolition waste management model based on system dynamics. Master's thesis, Shenzhen University, Shenzhen.

Yusuf, N., Kamaruddeen, A. M., \& Bahaudin, A. Y. (2016). Moderating effect of government policy on the relationship between organizational structure and construction waste management. Rev. Téc. Ing. Univ. Zulia, 39(1), 88-100.

Zikmund, W. G., Babin, B. J., Carr, J. C., \& Griffin, M. (2013). Business research methods: Cengage Learning. 